\section{日本臨床外科学会山梨県支部抄録 (第78回山梨県臨床外科医学会)}

\author{
会 期：平成29年11月11日（土） \\ $14: 00 \sim 15: 30$ \\ 会場：山梨大学医学部基礎研究棟 6 階大会 \\ 議室 \\ 当番世話人：JCHO 山梨病院 外科 安村友敬
}

\begin{abstract}
1 多発性末梢性乳管内乳頭腫の 1 例
山梨大学医学部第一外科

$\bigcirc$ 望月理玄, 大森征人, 仲山 孝, 中山裕子, 木村亜矢子, 高橋 ひふみ, 井上慎吾, 市川大輔

乳管内乳頭腫は孤立性と多発性に分類され、多発性乳管内乳頭腫 は癌との関連性が高く、覀性腫瘍の併発、続発を念頭に置いた治 療が推奨される。今回、術前に多発性末梢性乳管内乳頭腫と診断 し、切除した症例を経験したため報告する。症例は48歳女性、右 乳頭の血性分泌と腫瘤を自覚し、近医を受診後、当科に紹介とな った。エコーで右乳腺 B 領域の乳頭下より連続する区域性の不整 乳管拡張を認め、内部に不整形の結節が多数存在した。MRIで は早期造影される多数の結節を認め、針生検で乳管内乳頭腫の診 断に至った。多発性末梢性乳頭腫の診断で右乳腺腺葉区域切除術 を施行、術後経過良好で第 3 病日に退院した。病理ではintraductal papilloma with atypical ductal hyperplasiaと診断された。 過去の報告を含め、若干の文献的考察を加えて報告する。
\end{abstract}

\footnotetext{
2 上腸間膜動脈閉塞症患者に血管内治療を行った後、手 術を施行した 1 例 市立甲府病院外科

○塚原 勇, 樫本健太郎, 柴 修吾, 國友和善, 角田 元, 千須 和寿直, 宮澤正久, 飯野 弥, 巾 芳昭

症例は62歳男性で既往歴に特記事項なし。昼食後より腹痛、嘔吐、 下㾥が出現し 6 時間後に当院救急外来を受診した。受診時、上腹 部を中心に硬く自発痛圧痛があり、腹部造影 CTでSMA 根部か ら低吸収領域を認め末梢が造影されていなかった。またSMVの 一部も造影欠損し、広範な小腸壁の造影不良を認めた。そこで腸 管の切除範囲滅少を目的とした血管内治療を施行する方針となっ た。発症より11時間の時点で血栓吸引療法を開始、ウロキナーゼ 48万単位を使用した血栓溶解療法を併用し 6 割程度の血管描出が 可能となった。その後の開腹所見ではトライツ䩲帯より約 $25 \mathrm{~cm}$ のところから、約 $2 \mathrm{~m}$ の小腸の色調変化を認め切除した。残存小 腸は約 $2 \mathrm{~m}$ となった。引き続き口側、肛門側の小腸で双孔式の人 工肛門造設を行った。術後、新たな腸管虚血の所見なく全身状態 も良好であったため、8 日目に人工肛門閉鎖術を施行し、20病日 目に軽快退院となった。今回 SMAO患者の術前に血管内治療を 行い、腸管切除範囲を狭められたと考えられた症例を経験したの で報告する。
}

3 CLEAN-NETにて腹胿鏡下胃局所切除術を施行した 胃 glomus 腫瘍の 1 例

山梨大学医学部第一外科

$\bigcirc$ 若菜弘幸, 河口賀彦, 中田祐紀, 白石謙介, 赤池英憲, 渡邊光 章, 細村直弘, 雨宮秀武, 川井田博充, 須藤 誠, 河野 寛, 井 上慎吾, 市川大輔

症例は56歳、女性。貧血精查の上部消化管内視鏡検查で胃体下部 後壁に頂部に delleを有し内腔へ突出する $30 \mathrm{~mm}$ 大の粘膜下腫瘤 を認めた。超音波内視鏡検査では第 4 層に連続する低エコー腫瘤 として描出された。造影 CT 検査では、内部に動脈相で造影効果 が増強し遲延相でも効果が遷延する部位を有する円形腫瘤として 指摘された。内視鏡生検の病理組織診断では、血管増生を伴い不 規則に配列する棈円形核の腫瘍細胞を認め、免疫染色でSMA 陽 性、desmin一部陽性、CD34、c-kit、S-100蛋白が陰性であり、 胃 glomus腫瘍を強く疑う所見であった。症例はdelleを有する内 䏕突出型の $30 \mathrm{~mm}$ 大の胃粘膜下腫瘍であり、穿孔式手術による腫 瘍細胞の腹腔内播種の危険性を回避するために、CLEAN-NET (combination of laparoscopic approaches to neoplasia with nonexposure technique）による腹腔鏡下胃局所切除術を施行した。 内䏶突出型の胃粘膜下腫瘍に対する腹腔鏡治療について、これま での当科における腹腔鏡手術内視鏡合同切除術 (LECS) の治療 経験と文献的考察をふまえて報告する。

4 悪性リンパ腫との鑑別が困難であり，腹腔鏡補助下回 盲部切除術を施行したメトトレキサート関連リンパ増殖性疾患 (MTX-LPD) の 1 例

菲崎市立病院

○齊藤 亮, 鈴木 修, 平井 優

症例は68歳，女性．関節リウマチに対し 9 年前よりメトトレキサ 一ト (MTX), タクロリムスによる治療中であった。 3 ケ月持続 する倦急感を主訴に受診。血液検查で LDH 高值, 可溶性 IL- $2 \mathrm{R}$ 高值，また腹部造影 CT で終末回腸の壁肥厚と周囲リンパ節腫大 を認めた. MTX-LPDの可能性を考えMTXを中止した， 2 週間 後の下部消化管内視鏡検查で終末回腸のびらん性変化を認め, 同 部位からの生検では悪性リンパ腫が疑われたが, 確定診断には至 らなかった．診断及び治療目的に腹腔鏡補助下回盲部切除術を施 行した。手術検体の肉眼所見では回腸粘膜に潰瘍形成を認め, 周 囲に腫大リンパ節を認めた，組織学的には滤胞様結節を形成する atypical lymphoid cellが全層性に浸潤増殖していた。リンパ腫が 疑われたが, 免疫染色では特定の悪性リンパ腫と診断できる所見 はなく, atypical lymphoid hyperplasiaの診断となった. MTX 内服の既往と合わせ，MTX-LPD と考えられた。

MTX-LPD はMTX 投与中に発症するリンパ増殖症とされ，良性 のリンパ球増殖から悪性リンパ腫まで様々な形態を呈する．節外 病変が多く, 皮膚, 口䏶・咽頭, 肺などの報告が大半であり, 小 腸の報告例は稀である。一般的には MTXの中止のみで自然消退 が得られる症例が $30 \%$ ほどあるとされ，その変化は 2 週間程度で 確認されることが多いとされている. 自験例ではMTXを中止し 2 週間後の内視鏡検查でも小腸潰瘍の局所の所見が残存し，同部 位からの生検でも悪性リンパ腫との鑑別が困難であった。そのた め切除の方針とし，切除検体の評価により最終診断に至った．今 回我々は終末回腸に発症したMTX-LPD と考えられる 1 例を経 験したため，文献的考察を加えて報告する. 
5 Meckel㮩室が原因であった腸閉塞に対して腹䏶鏡下 手術が有用であった 1 例

山梨県立中央病院外科 ${ }^{1}$, 山梨県立中央病院病理 ${ }^{2}$

鷹野敦史 ${ }^{1}$, 渡邊英樹 ${ }^{1}$, 池亀 昂 $^{1}$, 中田晴夏 ${ }^{1}$, 山本淳史 ${ }^{1}$, 井 上正行 ${ }^{1}$, 古屋一茂 ${ }^{1}$, 安留道也 ${ }^{1}$, 羽田真朗 ${ }^{1}$, 宮坂芳明 ${ }^{1}$, 飯室勇二 ${ }^{1}$, 中込 博 ${ }^{1}$, 小山敏雄 ${ }^{2}$

症例は32歳男性。主訴は腹痛、嘔吐。突然の腹痛、嘔吐を自覚し て、近医受診。感染症の診断にて内服と点滴されるも改善なし。 当院 2 次救急を受診し、開腹歴のないイレウスの診断となり外科 入院となる。CTにて右下腹部に閉塞部位あり。絞抳所見ないた め、保存的治療を開始。イレウス管留置して滅圧するもイレウス 管造影検查で小腸の狭窄像あり。保存的治療で改善は困難と判断 して、腹腔鏡下イレウス解除術を施行。手術所見としては、回腸 末端より $120 \mathrm{~cm}$ の腸間膜対側に $10 \mathrm{~cm}$ 程の Meckel䄸室あり。 Meckel唕室の先端が小腸間膜に癒着して、Meckel憩室自体がバ ンドとなり、内ヘルニアを形成。内ヘルニアを解除して、小開腹 をおきMeckel喤室を含め小腸部分切除を施行した。術後経過問 題なく退院なった。Meckel㮩室は術前診断が困難なため、腹腔 鏡下手術が診断かつ治療に有用であったとする報告が散見され る。今回われわれが経験した症例においても診断、治療の両面に おいて腹腔鏡下手術が有用であったため、若干の考察を加えて報 告する。

6 大腸癌肝転移を化学療法後に切除し黄色肉芽腫性変化 によりCRが証明された症例

富士吉田市立病院外科 ${ }^{1}$, 山梨大学医学部人体病理 2

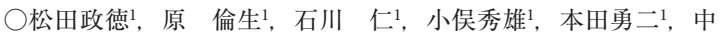
澤匡男 ${ }^{2}$

症例は50歳代、女性。腹部膨満を主訴に近医受診し、CFにて下 行結腸癌 (Type 2) と診断され紹介入院した。精查で肝S 8 に $2.9 \mathrm{~cm}$ の肝転移が発見された。CEAは $5.3 \mathrm{ng} / \mathrm{ml}$ 。下行結腸切除 D 3 リンパ節廓清を実施。病理診断は、中分化管状腺癌 (KRAS wild)、D, Type $2,5.0 \times 5.0 \mathrm{~cm}$, tub 2 , pT 3 , int, INFb, ly 1 , v 0 , pPN 0, pPM 0, pDM $0, \mathrm{pRM} 0, \mathrm{cR} 2, \mathrm{pN} 0(0 / 14), \mathrm{cM} 0, \mathrm{cH}$ $1, \mathrm{cP} 0, \mathrm{cPLU} 0$, cStageIV。術後 3 週後のCT 検査で、S 8 の腫 瘍は6.0x $5.0 \mathrm{~cm}$ と著明に増大していた。術後 1 ヶ月から FOLFIRI +C-mabを 9 コース実施した。終了時、S 8 の腫瘤は $1.8 \mathrm{~cm}$ に縮 小し、新病変は認めなかった。S 8 単発の転移性肝癌の診断で結 腸切除から 7 か月後、肝前区域部分切除、胆摘を実施した。切除 標本の肉眼的検索で、肝被膜直下に $2.0 \times 1.2 \mathrm{~cm}$ の黄白色調の充実 性腫瘤を認め、組織学的に泡沫細胞主体でリンパ球、形質細胞、 好酸球などの炎症性細胞浸潤に粘液結節を伴う病変で黄色肉芽腫 と診断した。また、腫瘍細胞の遺残はなく（Grade 3) CRであ った。大腸癌肝転移が化学療法後に黄色肉芽腫性変化により CR となった報告はなく、稀な症例と考え報告する。

7 鏡視下手術時のドレーン留置の工夫

都留市立病院外科

○岡本廣挙, 高橋和徳, 川島健司, 深澤敏男

【背景】最近は、腹部手術において陰圧、閉鎖式ドレーンの使用 とその早期抜去が奨励されているが、ドレーンの重要性は変わら ない。鏡視下手術時も同様であるが、時にその逸脱も経験する。目 的】鏡視下手術のポート孔を用いたドレーン留置が逸脱の原因と 考え、その挿入法に工夫を試みた。【対象と方法】ドレーンは、 閉鎖式ラウンドタイプのマルチチャンネルを用いている。挿入法
は、皮膚のポート挿入創をそのまま利用して、目的部位に直線的 となるようトラカールを再挿入して腹膜外ルートを作成し、でき るだけ屈曲のないよう角度をつけて挿入した(腹膜外法)。対象は、 従来の方法でドレーンを挿入した症例（従来法）と腹膜外法の症 例で、術後のレントゲン写真を用いて冕脱を比較検討した。結果】 腹膜外法では、従来法に比べて術後のドレーンの逸脱が少なかっ た。【考察】比較症例の蓄積が必要ではあるが、鏡視下手術のド レーン挿入法は、腹膜外法が有用である。 